\title{
A narrative review of interventions addressing the parental-fetal relationship
}

Nicole Borg Cunen RM, MSc ${ }^{a,{ }^{*}}$, Julie Jomeen RM, $\mathrm{PhD}^{b}$, Rita Borg Xuereb RM, $\mathrm{PhD}^{\mathrm{a}}$, Angela Poat RM, $\mathrm{PhD}^{\mathrm{b}}$

${ }^{a}$ Department of Midwifery, Faculty of Health Sciences, University of Malta, Msida, MSD 2080, Malta

${ }^{b}$ Department of Midwifery and Child Health, Faculty of Health and Social Care, University of Hull, HU6 7RX, UK

* Corresponding author: Rm 47, Department of Midwifery, Faculty of Health Sciences, University of Malta, Msida, MSD 2080, Malta. Tel. +356 23401895, +356 79230187.

Email Address: n.borg-cunen@2014.hull.ac.uk 


\section{A narrative review of interventions addressing the parental-fetal relationship}

\section{Abstract}

Background: Expectant parents are thought to develop varying degrees of emotional affiliation with the unborn child. Interventions supporting this relationship may be beneficial given its link to maternal health behaviour during pregnancy, as well as the parental-infant bond after birth.

Aim: To identify, and describe the effects of, programmes and strategies that have addressed the parental-fetal relationship.

Method: English-language primary studies, published between 2005-2015, were identified and their methodological quality was assessed. Databases used included CINAHL, Cochrane Library, MEDLINE, PsycINFO and Web of Science. Key search terms included maternal/paternal-fetal attachment, prenatal bond, parental-fetal relationship and intervention. RCTs, non-RCTs, observational and non-comparative studies, before and after studies and case studies were included.

Findings: Twenty-seven studies were included. Studies evaluated the effects of various strategies, including ultrasound and screening procedures, fetal awareness interventions, social and psychological support techniques, educational programmes and relaxation strategies. Results are inconsistent due to the diversity of interventions, and significant variation in methodological quality.

Conclusion: There is insufficient evidence to support definitive conclusions regarding the efficacy of any included intervention. A number of limitations, such as non-probability sampling, lack of blinding, and insufficient follow-up weaken the evidence. The inclusion of fathers in only 
three studies reflects the overall neglect of men in research regarding the prenatal relationship. Further in-depth study of the nature of the maternal/paternal-fetal relationship may be needed in order to allow for the identification of interventions that are consistently beneficial and worthwhile.

Keywords: Maternal-Fetal Relations, Paternal-Fetal Attachment, Psychological Bonding, Review, Interventions, Prenatal Care.

\section{Abbreviations}

RCT - Randomised Controlled Trial

PFR - Parental-Fetal Relationship

MFR - Maternal- Fetal Relationship 


\begin{tabular}{|l|l|}
\hline \multicolumn{2}{|c|}{ Statement of Significance/Summary of Relevance } \\
\hline Issue: & $\begin{array}{l}\text { Expectant parents develop different degrees of connectedness } \\
\text { to the unborn child. This is thought to be determined by a } \\
\text { combination of risk and protective factors. Interventions } \\
\text { supporting this relationship could have long-term beneficial } \\
\text { influences. }\end{array}$ \\
\hline What is Already Known: & $\begin{array}{l}\text { Previous research has suggested that a robust parental-fetal } \\
\text { relationship is linked to more positive maternal health behaviour } \\
\text { during pregnancy, as well as secure parental-infant bonds after } \\
\text { birth. }\end{array}$ \\
\hline What this Paper Adds: & $\begin{array}{l}\text { There is insufficient evidence to reach definitive conclusions } \\
\text { regarding the efficacy of reviewed interventions. The construct } \\
\text { of parental-fetal relationships lacks conceptual clarity. Inductive } \\
\text { research may be necessary prior to the development of }\end{array}$ \\
\hline
\end{tabular}




\section{$\underline{\text { Introduction }}$}

Over the past fifty years there has been increasing recognition that the development of the relationship between parents and their infants begins prior to birth, during the antenatal period 1 . Pregnant women adapt to their pregnancy, and their impending motherhood role, in varied ways, and there are individual differences in the degree of connectedness, or emotional affiliation, they develop towards their unborn child ${ }^{2}$. In this respect, the parental-fetal relationship (PFR) is thought to "be related to cognitive and emotional abilities to conceptualise another human being" ${ }^{3(p 185)}$, and to be influenced by societal context ${ }^{4}$. For each individual expectant parent, the quality of the fetal relationship is believed to be determined by a unique combination of risk and protective factors ${ }^{5}$.

It has been hypothesised that studying the PFR offers a unique opportunity to understand the way in which the child is envisioned by each of his/her parents, which is uncomplicated by early parenting experiences, and infant temperament ${ }^{6}$. The importance of gaining knowledge about the development of the PFR during pregnancy lies in its surmised link to parental-infant attachment that occurs after birth. Through this pathway, the PFR is believed to play a critical role in the child's well-being and emotional and cognitive development ${ }^{7,8}$. The maternal-fetal relationship (MFR) is thought to also be associated with mothers' health behaviours and selfcare during pregnancy ${ }^{9}$.

It has been widely suggested that the PFR is a cumulative process, developing over the gestational period ${ }^{10,11 .}$ However, other predictors and correlates of the PFR are less certain, with related research being characterised by highly inconsistent results ${ }^{2,10}$. It is, for instance, unclear how psychological health in the antenatal period may influence the PFR. While some research has suggested a link between psychological compromise and a less positive prenatal relationship ${ }^{9,12,13}$, others have discredited such an association ${ }^{14,15}$.

Attempts to link social support to the PFR have similarly been marred by inconsistencies. 
Tentative conjectures based on available research suggest that in vulnerable populations, such as adolescent mothers ${ }^{16}$, and socio-economically disadvantaged individuals ${ }^{17}$, the MFR may be stronger in the presence of adequate social support. However, the influence of social support is less clear in non-vulnerable populations ${ }^{18,19}$.

Such correlational inconsistences may stem from contrasting conceptualisations of the bond ${ }^{20,21}$, which has resulted in a plethora of tools measuring different aspects of the construct. The use of attachment theory as a guiding principle in existing conceptualisations has been questioned, with researchers objecting to the term 'attachment' being used to describe the parent-to-child aspect of familial relationships, rather than the reverse, as was originally intended by Bowlby ${ }^{21,22}$. Furthermore, there is a paucity of studies looking into the paternal aspect of the prenatal relationship, despite the knowledge that fathers', as well as mothers', develop conceptualisations of, and express feeling of closeness towards, their infants in the prenatal period ${ }^{23}$.

Despite these issues a growing number of researchers have attempted to develop interventions to address the PFR. If the PFR indeed represents the beginnings of parental conceptions about the child, then supportive interventions of this kind could have important implications for both the parents and the child in the perinatal period and beyond. The purpose of the narrative review is to identify, and describe the effects of, programmes and strategies that have addressed the PFR.

\section{Methods}

\section{Search Strategy}

A search strategy was formulated, and searches of major relevant databases were conducted in November 2015. The databases used included CINAHL, Cochrane Library of Controlled Trials, MEDLINE, PsycINFO and Web of Science. Pertinent search terms, as illustrated in Figure I, were used in pre-determined combinations. 
The relevance of the retrieved papers to the PFR was initially established through a screening of titles and abstracts. If it was determined that a paper might be eligible, the full text was obtained. The acquired papers were then read in their entirety to establish whether they met eligibility criteria for inclusion in the review. In addition, a manual search of the reference lists of relevant articles was carried out in order to identify further eligible publications, and search alerts were set up on the identified databases for notification of new results on saved searches.

Papers considered eligible for inclusion were those which: focused on an intervention that addressed the PFR; were published between 2005-2015; in English; and consisting of research of quantitative or mixed methodology. Randomised and non-randomised controlled trials (RCTs and non-RCTs), observational and non-comparative studies, before and after studies, and case studies were all included. Papers were excluded if they did not have a relevant outcome measured in the antenatal period, or if they took the form of editorials, commentaries, conference proceedings or features. Eligibility for inclusion was initially conducted by the primary author (NBC), and subsequently discussed with co-authors (JJ, RBX and $A P$ ) to reach a final decision.

Data was extracted through the use of a data collection form incorporating attributes of the research such as purpose and design, as well as strengths and limitations. Table I provides a detailed summary of the included papers.

\section{Data Quality Assessment}

The included papers were evaluated to assess the risk of bias within the research, and to determine the extent to which their findings could be generalised to the source population. This facilitated discernment of the level of confidence that should be placed on the conclusions drawn. For assignment of a quality level to each eligible study the 'quality appraisal checklist 
for intervention studies' was used. This checklist forms part of the revised 'Graphical Appraisal Tool for Epidemiological Studies (GATE)', developed by Jackson et al. ${ }^{24}$ and revised by NICE

${ }^{25}$. It allows for the assignment of hierarchal scores to separately indicate the study's internal and external validity. The scores range from '++' through to '-', as determined by whether vital criteria are fulfilled. Key aspects of study design are appraised, including population criteria, method of allocation to intervention and control conditions (where applicable), and methods of analysis. The checklist requires the reviewer to account for the decisions made with regards to quality determination both in relation to the individual items, and with regards to overall study ratings.

\section{Findings}

The literature search identified a total of 1,777 papers, of which 1,557 papers remained following removal of duplicates. The titles were screened for relevance to the PFR, and 1,038 irrelevant records were excluded. Of the remaining 519 records, following a review of abstracts, papers deemed to not be directly relevant to the primary aim of this review were removed $(n=296)$. A further 20 potentially eligible papers were identified though search alerts and reference list checks. The full text of 243 papers was obtained for further investigation. A total of 27 papers, concerning interventions addressing the PFR, met the eligibility criteria. The flow chart in Figure II details the number of papers present at each stage and reasons for omissions.

The eligible papers comprised 15 RCTs, 1 non-RCT, 3 observational studies, 2 before and after studies with non-concurrent groups, 5 non-comparative studies, and a single case study. They originated in Europe $(n=10)$, USA $(n=9)$, Asia $(n=6)$, and Australia $(n=2)$. The studies evaluated the effects of various intervention strategies, including ultrasound and screening procedures $(n=9)$, fetal awareness interventions $(n=3)$, social or psychological support 
techniques $(n=6)$, educational programmes $(n=5)$ and relaxation strategies $(n=4)$. Sample size ranged from $1^{26}$ to $2986{ }^{27}$ participants.

All the studies used self-report tools to measure the PFR, with eleven of the studies using the original or modified versions of Maternal/Paternal-Fetal Attachment Scale (MFAS ${ }^{28} /$ PFAS $^{29}$ ), seven using the Maternal/Paternal Antenatal Attachment Scale (MAAS/PAAS) ${ }^{6}$, a further seven using the Prenatal Attachment Inventory (PAI) ${ }^{30}$, and four using lesser known, or selfdeveloped tools.

The majority of the studies comprised female participants $(n=24)$, while a few included both men and women $(n=2)$, or men alone $(n=1)$. Various personnel, including psychologists/psychotherapists, midwives, nurses, mental health professionals, yoga instructors, trained mentors, or ultrasonographers/radiographers facilitated the interventions. The prenatal relationship was measured between one and four times over the course of the study, with the majority of studies measuring it twice $(n=17)$. Many of the studies had no followup after the intervention conclusion, with the longest follow-up period for the measurement of the PFR being one month ${ }^{31}$.

Assigned quality ratings varied, but none of the eligible studies were awarded a '++' rating for either external or internal validity. Instead grades ranged from ' + ' to '-', indicating that validity was either mixed or poor. Fourteen of the studies received a '+' rating for internal validity, while the remaining 13 were awarded a '-' rating, indicating that conclusions would be likely, or very likely to alter. With regards to external validity, 14 papers similarly received a '+' rating, while 13 received a '-' rating. Ratings for internal validity were not necessarily reflective of those for external validity.

\section{Ultrasound Imaging and Screening Procedures}


The identified papers most commonly assessed the influence that undergoing ultrasound examinations or other screening tests may have on the PFR. In one such study, Pretorius et al. ${ }^{32}$ determined that there was a significant increase in the strength of the fetal relationship for both women $(n=124)$, and their male partners $(n=65)$, from immediately prior to following a 3/4- dimensional ultrasound examination. However, the lack of a control group makes it impossible to determine whether short-term maturation effects, possibly affected by completing the same measure twice within a short period, influenced results. Conversely, in an RCT with 52 female participants, Boukydis et al. ${ }^{33}$ found that the MFR did not change significantly from pre- to post-test in a group of women who received a routine obstetric ultrasound examination, but did increase significantly for a group who, in addition to the ultrasound, received a detailed explanation of the ultrasound findings, as well as postsession debriefing. This suggests that communication about ultrasound findings rather than the examination itself may influence the MFR. In another RCT, Kleinveld et al. ${ }^{27}$ found that offering expectant mothers' pregnancy screening tests, either through ultrasound or through blood analysis, did not greatly impact the MFR, at least in the case of reassuring results. However, the validity of the latter findings is called into question given the preferential use of a self-developed tool which included items relating to pregnancy involvement, impairing its capacity to focus on the MFR.

Other research has looked at the influence of the timing and focus of an ultrasound examination on the MFR. In a RCT, Ohman and Waldenstrom ${ }^{34}$, found that women who received a risk-focused ultrasound in the first trimester had a stronger MFR at 24 weeks gestation than women undergoing a routine ultrasound in the second trimester. The researchers contend that earlier visualisation of the fetus may reassure parents and reinforce the reality of pregnancy, encouraging the development of the MFR from an early stage of pregnancy. The omission of baseline measurement of the MFR does not allow confidence that the groups were initially equivalent. However, the results are supported by a study by Sedgmen et al. ${ }^{35}$, which, using a controlled pre-, post-test design, also explored the impact 
of timing of ultrasound exposure on the MFR. They found that the increase in scores on the MFR measure after an ultrasound examination were much greater for participants undergoing their first ultrasound at approximately 12 weeks' gestation, than for those who were having a repeat ultrasound at 18 weeks' gestation.

The remaining studies that looked into ultrasound examination in relation to the PFR compared the impact of 2D versus 3D or 4D ultrasound imaging modalities. All such studies came to the conclusion that, while the PFR often improved following, as compared to prior to, the ultrasound examination, disparate ultrasound imaging modalities did not appear to affect the PFR to differing degrees, either for mothers ${ }^{35-39}$, or for fathers ${ }^{36}$. The individual studies have significant methodological limitations that restrict the generalisability of their results. Nevertheless, taken together, they present a convincing cluster of mostly homogeneous results.

\section{Fetal Awareness Interventions}

Becoming more conscious of the fetus, through experiences such as quickening, may reinforce the conception of the fetus as a person in his/her own right ${ }^{40}$. Researchers have hypothesised that inducing further awareness of the fetus may serve to enhance the MFR. Two RCTs have found contradictory results regarding the effects of fetal movement counting on the MFR. Rincy and Nalini ${ }^{41}$, in an Indian study with a sample of 100 participants, found that for a group of women assigned to monitor fetal movements for two weeks, scores relating to the MFR increased significantly, leading these women to have significantly higher scores than those in the control group in the post-intervention period. However, a larger Norwegian study by Saastad et al. ${ }^{42}$ found opposing results. No significant group differences were found in post-intervention scores relating to the MFR between a group of expectant mothers assigned to systematic fetal movement counting from pregnancy week $28(n=478)$ and a control group ( $n=473)$. The differing results in these two studies may have been influenced by a number of factors, such as disparate timing of the intervention, and 
differences between study populations. Although the larger sample size, and longer intervention period, in the study by Saastad et al. ${ }^{42}$ may mean that it was able to more accurately recognise the (lack of) difference between groups, the omission of preintervention measurement of the MFR results in uncertainty about the initial equivalence of the study and control groups.

Results from an observational study carried out in Japan, by Nishikawa and Sakakibara ${ }^{43}$, suggest that a nursing intervention programme using abdominal palpation to demonstrate fetal position may improve the MFR in expectant mothers $(\mathrm{N}=227)$. While between-group scores relating to the MFR were similar at baseline, the intervention group scored significantly higher than the control group at 34 and 36 weeks' gestation. However, a high dropout rate over the course of the study $(52.4 \%)$, suggests the possibility of attrition bias. Furthermore, given the use of non-random assignment to groups, self-selection bias may also have been in play.

Given methodological differences and inconsistent results in existing research, it is as yet unclear whether interventions attempting to induce heighted fetal awareness can truly allow the expectant mother to develop a stronger connection with her unborn child.

\section{Educational Programs}

Antenatal education has long been known to have beneficial effects on knowledge and confidence for expectant mothers ${ }^{44}$. Researchers have explored the influence of specifically designed antenatal education programs, often with a focus on attachment training, on the MFR. Although all the educational interventions included in the review saw an increase in the strength of the MFR over time, two of the studies were of non-comparative design ${ }^{45,46}$ and one was an observational study where participants self-selected into groups ${ }^{47}$. The use of such research designs leads to uncertainty regarding causality. The two RCTs which focused on an educational intervention ${ }^{31,48}$ give stronger evidence of intervention efficacy. However, here too are methodological issues that limit validity, with Abasi et al. ${ }^{48}$, for instance, omitting 
details such as the number of women in each group and method of randomisation. The RCT by Akbarzade et al. ${ }^{31}$, conducted in Iran, is innovative in that it investigated the effect of providing attachment training to expectant fathers, on the MFR in the men's wives. The researchers suggest that addressing the male in an intimate partner relationship may serve to instil a sense of responsibility in the father, and drive his involvement in the pregnancy care process, thus having an indirect effect on the MFR. It is unclear why the paternal-fetal relationship was not measured in this study, and it would have been interesting to observe whether this was similarly improved by the intervention, and whether it correlated with the MFR.

Overall, the studies that have used educational programmes in an attempt to boost the MFR have methodological limitations that make arrival at definitive conclusions difficult.

\section{Social and Psychological Support Techniques}

A number of studies included in this review have investigated the influence of psychological therapies, or caring-based support interventions employed to boost emotional health, on the PFR. Rationale for including a measure of PFR in such studies is often based on a surmised link between emotional well-being and more positive maternal conceptualisations of the unborn child, although this link has not been consistently supported in the literature ${ }^{10}$.

Looking first at those studies that made use of social support techniques, a RCT by Weis and Ryan ${ }^{49}$ evaluated the effectiveness of a mentorship program, with a sample of 65 expectant military wives whose husbands were deployed for at least one month during the gestational period. A second study, by Cote-Arsenault et al. ${ }^{50}$, tested the feasibility and acceptability of a nursing home visit intervention with 24 women who were pregnant after a prior perinatal loss. The latter study, mixed methods research conducted in the USA, comprised a small RCT, with a qualitative element. Neither study found significant differences in MFR related scores between the post-test results of intervention and control groups. However, from the qualitative analysis in the study by Cote-Arsenault et al. ${ }^{50}$, it was determined that half of the 
women felt that the intervention lessened their tendency to avoid attaching to their unborn child during the current pregnancy, due to a fear of repeat loss.

Research looking an intervention more directly based on psychological principles also failed to detect relevant between-group differences in the post-intervention period. Spinelli et al. ${ }^{51}$, in a RCT with sample of 142 women who met DSM-IV criteria for major depressive disorder, examined the effectiveness of interpersonal psychotherapy for antepartum depression, as compared to a routine parenting education programme. MFR scores did not appear to differ notably between groups at any point during the treatment. The researchers suggest that the parenting education programme may have had similar benefits to the psychotherapy intervention, in terms of facilitating the MFR. The study is limited by a relatively high attrition rate $(37.3 \%)$, which raises questions about its external validity.

In other psychologically-based research, Scherer et al. ${ }^{26}$ used case study methodology to examine the applicability of a psychologist-supervised, online, self-help programme, for anxiety and stress management, in pregnant women with preterm labour. It is illustrated by the case of an expectant mother who had been hospitalised with the pregnancy complication. The strength of the woman's MFR improved over the course of the treatment. However, given the methodology, and the lack of untreated control patients, any causal inferences about the observed changes are not justified.

A further two studies looking at emotional wellbeing were not restricted to the antenatal period, spanning, instead, the transition to parenthood ${ }^{52,53}$. Lavi et al. ${ }^{53}$, in non-comparative research, examined the impact of a Child- Parent Psychotherapy programme with a sample of 94 women who had a history of trauma, on maternal functioning at 6 months postpartum. The greatest improvement in depression, posttraumatic stress symptoms, and child-rearing attitudes was observed in women who initially reported a weak MFR. The researchers' hypothesis that an initially weak MFR may identify those at high-risk of maladaptive parenting behaviours, who stand to benefit most from such an intervention. In the second study, Flykt 
et al. ${ }^{52}$ analysed change in maternal representations of the unborn child over the transition to parenthood among 51 drug-abusing mothers, who either participated in psychodynamic group therapy or received psychosocial support, and among 50 non-drug using comparison dyads. The authors suggest that the mild, non-significant positive change in maternal representations seen among the psychodynamic group therapy participants suggests that the intervention helped the vulnerable, high-risk women to build a sustained, positive view of the infant, preventing idealisation of the infant, and subsequent disillusionment. However, it is important to keep in mind that use of participant self-selection into groups introduces the possibility that systemic differences between groups may have influenced their representational change over time.

In summary, caring-based social support interventions do not appear to enhance the MFR, based on the statistical results of the two studies included in this review. Yet, results from the qualitative component of the study by Cote-Arsenault et al. (2014), suggests that there were intricate effects of the programme on the MFR that were not detected, or explored effectively, with the use of self-report tools and quantitative methodology. Neither can any conclusions be drawn regarding the effects of psychologically based interventions on the MFR in at-risk populations. This may be influenced by a lack of focus on prenatal attachment within these studies, with the MFR being regarded as secondary to outcomes relating more directly to psychological wellbeing.

\section{Relaxation Strategies}

Further capitalising on the tentative link between psychological heath and the PFR, other research has investigated the influence of various relaxation techniques that aimed to improve emotional wellbeing during pregnancy, and, through this pathway, boost the PFR.

Two studies have examined the effects of music listening on the MFR during pregnancy. In a Taiwanese RCT by Chang et al. ${ }^{54}$, comprising a sample of 320 expectant mothers, the intervention group were encouraged to listen to relaxation music for 30 minutes per day, over 
a two-week period. In the second study, of before and after controlled design, conducted in Korea, Shin and $\mathrm{Kim}^{55}$ played the intervention group $(n=117) 30$-minutes of music with nature sounds during a transvaginal ultrasound. Neither study found significant group differences related to the MFR in their post-test results. One should note, however, that both studies had limitations, with the former failing to record or control for routine music listening habits, and the latter making use of non-concurrent group outcome measurement, which may have confounded results.

In a more targeted intervention, using a non-comparative design, Muzik et al. ${ }^{56}$ explored the efficacy of a 10-week programme of mindfulness-yoga in improving the MFR, among 22 pregnant women with current and lifetime psychiatric diagnoses. Scores relating to the MFR increased significantly overall from pre, to post-intervention measurement. Unfortunately, the lack of a control group makes it impossible to establish causation, and it is likely that results were influenced by a maturation threat, changes in the MFR due to normal developmental processes.

In a final study investigating relaxation techniques, this time with expectant fathers, Latifses et al. ${ }^{57}$, examined the effects of men massaging their pregnant wives or practicing relaxation with them, on the men's relationship with the fetuses. The RCT compared 175 participants assigned either to a massage therapy group, a relaxation-training group, or a control group. Results indicated there were no significant pairwise comparisons in mean scores on the paternal-fetal relationship measure between groups, over time. However, omission of details such as the number of participants in each group calls into question the validity of the study.

It would appear that no definitive conclusions can be drawn regarding the influence of the various relaxation techniques on the PFR. Methodological limitations, widely differing interventions, and use of disparate self-report tools restrict our ability to draw accurate inferences.

\section{Discussion}


The detailed narrative review suggests that there is insufficient evidence to reach definitive conclusions regarding the efficacy of any of the included interventions in improving the PFR. Although some of the studies reviewed did find some evidence of positive effect, the results should be regarded with caution due to the considerable variance in methodological quality, and, at times, conflicting results. Furthermore, the significant heterogeneity in research design means that a coherent synthesis of results was not possible.

The only tentative deduction that can be made is with regards to the influence of ultrasound on the MFR. While undergoing an ultrasound, and receiving associated feedback, may allow mothers to better conceptualise, and feel closer to, their unborn child, the modality of the ultrasound appears to have little influence on the relationship ${ }^{35-39}$.

The reviewed studies share a number of methodological limitations that weaken the state of the available evidence as a whole. The use of a non- probability samples prevents assessment of representativeness, and inhibits inference from the sample to the wider population, thus restricting external validity ${ }^{58}$. A lack of, or insufficient, follow-up, as observed in the majority of the reviewed studies, prevents assessment of the longer-term effects of the intervention. Furthermore, the inability to blind participants and intervention facilitators to group allocation, a problem consistently encountered across the comparative studies reviewed, has been identified as a source of pronounced bias, often leading to exaggerated effect sizes ${ }^{59}$.

The inclusion of expectant fathers in only 3 of the 27 eligible studies reflects the overall neglect of men in research regarding the prenatal relationship. Although adapted tools exist to assess the paternal-fetal relationship, the greatest proportion of related research continues to focus on the expectant mother. This conflicts with the increasing recognition of the importance of fathers' involvement in their children's lives ${ }^{60}$.

The use of self-report tools to measure the PFR across the reviewed research has to be considered a major weakness. Data collected through questionnaires may be inadequate to 
allow an understanding of the PFR which is thought to be determined by complex interacting factors ${ }^{2}$. Questionnaires prevent respondents from explaining the thoughts behind their responses, and restrict responses to those options generated and imposed by the researcher, rather than allowing for self- determination of issues of importance ${ }^{61}$. Furthermore, as asserted by Saastad et al. ${ }^{42}$, repeat administration of PFR measures within a short period can cause biased results, as influenced by subconscious behaviour change based on the initial questionnaire. As already mentioned in the introduction of this review, within the field of PFR research, further concerns relate to the fact that existing tools have been built on the basis of conceptualisations that have questionably used attachment theory as a foundation ${ }^{21}$.

Most of the studies within this review that were of experimental, repeat-measure design, concluded that the intervention assessed was not more effective than the control condition in increasing the strength of the PFR. Non-significance of results possibly suggests that research within this area has not advanced to the extent required for the development of consistently beneficial and worthwhile interventions. Many of the interventions used do not appear to be substantiated by well-established links within the literature concerning the prenatal relationship, at times seemingly being applied in a trial and error approach.

\section{Limitations of the Review}

This paper was not intended to be a comprehensive or systematic review. It was designed, rather, to determine whether, given identified issues and inconsistencies in the research area, existing interventions are able to effectively support the PFR. It is acknowledged that the summary of evidence produced in a review is reliant on the quality of the primary research included. Thus, in the presence of inherent problems in design and execution of included research, the results of the review should be interpreted with caution ${ }^{62}$.

\section{Conclusions and Recommendations for Further Research}


This narrative review provides a summary of currently available evidence related to interventions addressing the PFR. On the basis of the eligible research, the review concludes that no identified intervention can currently be definitively recommended for use in clinical practice. The review serves to underline limitations in the current understanding of the social construct regarding the parental 'bond' with the fetus. Further inductive exploration of the PFR may be required, to allow for the building of an accurate theoretical framework ${ }^{40,63,64}$. Prior to the achievement of such an understanding, blind attempts to boost the PFR risk wasting of time and resources, and chance the possibility of causing harm.

\section{Acknowledgements}

The main author of this paper is a PhD student with the Department of Midwifery and Child Health at the University of Hull. She is in receipt of a scholarship from the University of Malta to pursue a PhD, but there is no conflict of interest in the reporting of data. The co-authors are supervisors of this PhD.

\section{$\underline{\text { References }}$}

1. Alhusen JL. A literature update on maternal-fetal attachment. JOGNN: Journal of Obstetric, Gynecologic \& Neonatal Nursing 2008; 37(3): 315-28.

2. Doan HM, Zimerman A. Conceptualizing prenatal attachment: Toward a multidimensional view. Journal of Prenatal \& Perinatal Psychology \& Health 2003; 18(2): 109-29.

3. Doan HM, Zimerman A. Prenatal attachment: Where do we go from here? International Journal of Prenatal and Perinatal Psychology and Medicine 2002; 14: 177-88.

4. Bielawska-Batorowicz E, Siddiqui A. A study of prenatal attachment with Swedish and Polish expectant mothers. Journal of Reproductive and Infant Psychology 2008; 26(4): 373-84.

5. Bouchard G. The role of psychosocial variables in prenatal attachment: An examination of moderational effects. Journal of Reproductive and Infant Psychology 2011; 29(3): 197-207.

6. Condon JT. The assessment of antenatal emotional attachment: Development of a questionnaire instrument. British Journal of Medical Psychology 1993; 66(2): 167-83.

7. Alhusen JL, Hayat MJ, Gross D. A longitudinal study of maternal attachment and infant developmental outcomes. Archives of Women's Mental Health 2013; 16(6): 521-9.

8. Condon J, Corkindale C, Boyce P, Gamble E. A longitudinal study of father-to-infant attachment: Antecedents and correlates. Journal of Reproductive and Infant Psychology 2013; 31(1): 15-30. 
9. Lindgren K. Relationships among maternal-fetal attachment, prenatal depression, and health practices in pregnancy. Research in Nursing \& Health 2001; 24(3): 203-17.

10. Yarcheski A, Mahon NE, Yarcheski TJ, Hanks MM, Cannella BL. A meta-analytic study of predictors of maternal-fetal attachment. International Journal Of Nursing Studies 2009; 46(5): 708-15.

11. Habib C, Lancaster S. Changes in identity and paternal-foetal attachment across a first pregnancy. Journal of Reproductive and Infant Psychology 2010; 28(2): 128-42.

12. McFarland J, Salisbury A, Battle C, Hawes K, Halloran K, Lester B. Major depressive disorder during pregnancy and emotional attachment to the fetus. Archives of Women's Mental Health 2011; 14(5): 425-34.

13. Alhusen JL, Gross D, Hayat MJ, Rose L, Sharps $P$. The role of mental health on maternalfetal attachment in low-income women. JOGNN - Journal of Obstetric, Gynecologic, and Neonatal Nursing 2012; 41(6): E71-E81.

14. Honjo S, Arai S, Kaneko H, Ujiie T, Murase S, Sechiyama H, et al. Antenatal depression and maternal-fetal attachment. Psychopathology 2003; 36(6): 304-11.

15. Della Vedova AM, Ducceschi B, Cesana BM, Imbasciati A. Maternal bonding and risk of depression in late pregnancy: A survey of Italian nulliparous women. Journal of Reproductive \& Infant Psychology 2011; 29(3): 208-22.

16. Diniz E, Volling BL, Koller SH. Social support moderates association between depression and maternal-fetal attachment among pregnant Brazilian adolescents. Journal of Reproductive and Infant Psychology 2014; 32(4): 400-11.

17. Zachariah R. Attachment, social support, life stress, and psychological well-being in pregnant low-income women: A pilot study. Clinical Excellence for Nurse Practitioners 2004; 8(2): 60-7.

18. Lewis MW. The interactional model of maternal-fetal attachment: An empirical analysis. Journal of Prenatal \& Perinatal Psychology \& Health 2009; 23(1): 49-65.

19. Maas AJBM, Vreeswijk CMJM, Braeken J, Vingerhoets AJJM, van Bakel HJA. Determinants of maternal fetal attachment in women from a community-based sample. Journal of Reproductive and Infant Psychology 2014; 32(1): 5-24.

20. Redshaw M, Martin C. Babies, 'bonding' and ideas about parental 'attachment'. Journal of Reproductive and Infant Psychology 2013; 31(3): 219-21.

21. Walsh J. Definitions matter: If maternal-fetal relationships are not attachment, what are they? Archives of Women's Mental Health 2010; 13(5): 449-51.

22. Bowlby J. Attachment and Loss: Vol.1. Attachment. New York: Basic Books; 1969/1982.

23. Vreeswijk CMJM, Maas AJBM, Rijk CHAM, van Bakel HJA. Fathers' experiences during pregnancy: Paternal prenatal attachment and representations of the fetus. Psychology of Men \& Masculinity 2014; 15(2): 129-37. 
24. Jackson R, Ameratunga S, Broad J, Connor J, Lethaby A, Robb G, et al. The GATE frame: Critical appraisal with pictures. Evidence Based Nursing 2006; 9(3): 68-71.

25. National Institute for Health and Care Excellence (NICE). Methods for the development of NICE public health guidance [PMG4]. [updated 2015 Dec 8; cited 2016 Mar 16]. Available from: https://www.nice.org.uk/article/pmg4/resources/non-guidance-methods-forthe-development-of-nice-public-health-guidance-third-edition-pdf.

26. Scherer S, Urech C, Hösli I, Tschudin S, Gaab J, Berger T, et al. Internet-based stress management for women with preterm labour: A case-based experience report. Archives of Women's Mental Health 2014; 17(6): 593-600.

27. Kleinveld JH, Timmermans DR, Berg M, Eijk JT, Kate LP. Does offering and performing prenatal screening influence women's attachment to their unborn child? A longitudinal randomized controlled trial. Prenatal Diagnosis 2007; 27(8): 757-64.

28. Cranley MS. Development of a tool for the measurement of maternal attachment during pregnancy. Nursing Research 1981; 30(5): 281-4.

29. Weaver RH, Cranley MS. An exploration of paternal-fetal attachment behavior. Nursing Research 1983; 32(2): 68-72.

30. Müller ME. Development of the Prenatal Attachment Inventory. Western Journal of Nursing Research 1993; 15(2): 199-215.

31. Akbarzade M, Setodeh S, Sharif $F$, Zare N. The effect of fathers' training regarding attachment skills on maternal-fetal attachments among primigravida women: A randomized controlled trial. International Journal Of Community Based Nursing And Midwifery 2014; 2(4): 259-67.

32. Pretorius DH, Gattu S, Ji EK, Hollenbach K, Newton R, Hull A, et al. Preexamination and postexamination assessment of parental-fetal bonding in patients undergoing 3-/4dimensional obstetric ultrasonography. Journal of Ultrasound in Medicine 2006; 25(11): 1411-21.

33. Boukydis CF, Treadwell MC, Delaney-Black V, Boyes K, King M, Robinson T, et al. Women's responses to ultrasound examinations during routine screens in an obstetric clinic. Journal of Ultrasound in Medicine 2006; 25(6): 721-8.

34. Ohman SG, Waldenstrom U. Effect of first-trimester ultrasound screening for Down syndrome on maternal-fetal attachment: A randomized controlled trial. Sexual \& Reproductive Healthcare 2010; 1(3): 85-90.

35. Sedgmen B, McMahon C, Cairns D, Benzie RJ, Woodfield RL. The impact of twodimensional versus three-dimensional ultrasound exposure on maternal-fetal attachment and maternal health behavior in pregnancy. Ultrasound in Obstetrics \& Gynecology 2006; 27(3): 245-51. 
36. Righetti PL, Dell'Avanzo M, Grigio M, Nicolini U. Maternal/paternal antenatal attachment and fourth-dimensional ultrasound technique: A preliminary report. British Journal of Psychology 2005; 96(Pt 1): 129-37.

37. Rustico MA, Mastromatteo C, Grigio M, Maggioni C, Gregori D, Nicolini U. Twodimensional vs. two- plus four-dimensional ultrasound in pregnancy and the effect on maternal emotional status: A randomized study. Ultrasound In Obstetrics \& Gynecology: 2005; 25(5): 468-72.

38. Lapaire O, Alder J, Peukert R, Holzgreve W, Tercanli S. Two- versus three-dimensional ultrasound in the second and third trimester of pregnancy: Impact on recognition and maternal-fetal bonding. A prospective pilot study. Archives of Gynecology and Obstetrics 2007; 276(5): 475-9.

39. de Jong-Pleij EA, Ribbert LS, Pistorius LR, Tromp E, Mulder EJ, Bilardo CM. Threedimensional ultrasound and maternal bonding, a third trimester study and a review. Prenatal Diagnosis 2013; 33(1): 81-8.

40. Laxton-Kane M, Slade $P$. The role of maternal prenatal attachment in a woman's experience of pregnancy and implications for the process of care. Journal of Reproductive and Infant Psychology 2002; 20(4): 253-66.

41. Rincy K, Nalini SJ. Effect of fetal movement counting on prenatal attachment and maternal worries among primigravidae. Asian Journal of Nursing Education \& Research 2014; 4(2): 224-7.

42. Saastad E, Israel P, Ahlborg T, Gunnes N, Frøen JF. Fetal movement counting. Effects on maternal-fetal attachment: A multicenter randomized controlled trial. Birth: Issues in Perinatal Care 2011; 38(4): 282-93.

43. Nishikawa M, Sakakibara $H$. Effect of nursing intervention program using abdominal palpation of Leopold's maneuvers on maternal-fetal attachment. Reproductive Health 2013; 10(1): 1-7.

44. Hillier CA, Slade P. The impact of antenatal classes on knowledge, anxiety and confidence in primiparous women. Journal of Reproductive and Infant Psychology 1989; 7(1): 3-13.

45. Burke CA. The effects of an 18-hour prenatal attachment program on maternal emotional attachment. US: Unpublished PhD thesis. Capella University; 2007.

46. Thomas N, Komiti A, Judd F. Pilot early intervention antenatal group program for pregnant women with anxiety and depression. Archives Of Women's Mental Health 2014.

47. Bellieni CV, Ceccarelli D, Rossi F, Buonocore G, Maffei M, Perrone S, et al. Is prenatal bonding enhanced by prenatal education courses? Minerva Ginecologica 2007; 59(2): 1259. 
48. Abasi E, Tafazzoli M, Esmaily $\mathrm{H}$, Hasanabadi $\mathrm{H}$. The effect of maternal-fetal attachment education on maternal mental health. Turkish Journal of Medical Sciences 2013; 43(5): 81520.

49. Weis KL, Ryan TW. Mentors offering maternal support: A support intervention for military mothers. JOGNN: Journal Of Obstetric, Gynecologic, And Neonatal Nursing 2012; 41(2): 303-14.

50. Cote-Arsenault D, Schwartz K, Krowchuk H, McCoy TP. Evidence-based intervention with women pregnant after perinatal loss. MCN-The American Journal of Maternal-Child Nursing 2014; 39(3): 177-86.

51. Spinelli MG, Endicott J, Leon AC, Goetz RR, Kalish RB, Brustman LE, et al. A controlled clinical treatment trial of interpersonal psychotherapy for depressed pregnant women at 3 New York City sites. The Journal Of Clinical Psychiatry 2013; 74(4): 393-9.

52. Flykt M, Punamäki RL, Belt R, Biringen Z, Salo S, Posa T, et al. Maternal representations and emotional availability among drug-abusing and nonusing mothers and their infants. Infant Mental Health Journal 2012; 33(2): 123-38.

53. Lavi I, Gard AM, Hagan M, Van Horn P, Lieberman AF. Child-parent psychotherapy examined in a perinatal sample: Depression, posttraumatic stress symptoms and childrearing attitudes. Journal of Social and Clinical Psychology 2015; 34(1): 64-82.

54. Chang $\mathrm{H}-\mathrm{C}, \mathrm{Yu} \mathrm{C}-\mathrm{H}$, Chen $\mathrm{S}-\mathrm{Y}$, Chen $\mathrm{C}-\mathrm{H}$. The effects of music listening on psychosocial stress and maternal-fetal attachment during pregnancy. Complementary Therapies in Medicine 2015; 23(4): 509-15.

55. Shin HS, Kim JH. Music therapy on anxiety, stress and maternal-fetal attachment in pregnant women during transvaginal ultrasound. Asian Nursing Research 2011; 5(1): 1927.

56. Muzik M, Hamilton SE, Lisa Rosenblum K, Waxler E, Hadi Z. Mindfulness yoga during pregnancy for psychiatrically at-risk women: Preliminary results from a pilot feasibility study. Complementary Therapies in Clinical Practice 2012; 18(4): 235-40.

57. Latifses V, Estroff DB, Field T, Bush JP. Fathers massaging and relaxing their pregnant wives lowered anxiety and facilitated marital adjustment. Journal of Bodywork and Movement Therapies 2005; 9(4): 277-82.

58. Ammaniti M, Baumgartner E, Candelori C, Perucchini P, Pola M, Tambelli R, et al. Representations and narratives during pregnancy. Infant Mental Health Journal 1992; 13(2): 167-82.

59. Reading AE, Cox DN, Sledmere CM, Campbell S. Psychological changes over the course of pregnancy: A study of attitudes toward the fetus/neonate. Health Psychology 1984; 3(3): 211-21. 
60. Davidson J. Non-probability (non-random) sampling. In: Jupp V, editor. The SAGE dictionary of social research methods. London: Sage Publications; 2006.

61. Hróbjartsson A, Emanuelsson F, Thomsen ASS, Hilden J, Brorson S. Bias due to lack of patient blinding in clinical trials. A systematic review of trials randomizing patients to blind and nonblind sub-studies. International Journal of Epidemiology 2014; 43(4): 1272-83.

62. Lamb ME. The role of the father in child development. 5th ed. New Jersey: John Wiley \& Sons; 2004.

63. Popper K. The logic of scientific discovery. London: Routledge; 2005.

64. Crowther MA, Cook DJ. Trials and tribulations of systematic reviews and meta-analyses. American Society of Haematology Education Program 2007; (1): 493-7.

65. Walsh J, Hepper EG, Bagge SR, Wadephul F, Jomeen J. Maternal-fetal relationships and psychological health: Emerging research directions. Journal of Reproductive and Infant Psychology 2013; 31(5): 490-9.

66. Birtwell B, Hammond L, Puckering C. 'Me and my Bump': An interpretative phenomenological analysis of the experiences of pregnancy for vulnerable women. Clinical Child Psychology and Psychiatry 2015; 20(2): 218-38 
Table I - Data Summary Table

\begin{tabular}{llll}
\hline $\begin{array}{l}\text { Authors } \\
\text { (Publication Year), }\end{array}$ & $\begin{array}{l}\text { Study Design, } \\
\text { Sample Size, } \\
\text { Location }\end{array}$ & Intervention & Key Relevant Outcomes Scale \\
Used
\end{tabular}

Ultrasound and Screening Tests

Boukydis et al 33

(2006)

USA
EG received a standard ultrasound screen, with the addition of extended consultation on fetal

development, maternal and familial responses, and maternal-fetal interaction.

CG received a standard ultrasound screen

de Jong-Pleij et al. ${ }^{39}$ (2013),

The Netherlands

\section{Before and After}

Study,

152 women

MAAS $^{6}$

\begin{abstract}
$\mathrm{CG}$ received a $2 \mathrm{D}$ ultrasound scan.
\end{abstract}
Kleinfeld et al. ${ }^{27}$

(2007)

The Netherlands

Lapaire et al. ${ }^{38}$

(2007),

Switzerland $\begin{array}{ll}\text { RCT, } & \text { EG1 was offered nuchal translucency } \\ 2986 \text { women, } & \text { measurement. }\end{array}$

Pregnancy

Involvement List, EG2 was offered maternal serum screening. $\mathrm{PAI}^{30}$

CG was not offered any screening.

RCT,

60 women,

Self-designed

questionnaire
EG1 received a 2D ultrasound, followed by a

3D ultrasound.

EG2 received a 3D ultrasound, followed by a 2D ultrasound.
MFR scores increased significantly from before No documented power

to after the ultrasound examination for the EG ( $\mathrm{p}$ analysis.

$<0.05$ ). The scores for the CG did not change significantly over time.

There were no significant differences in MFR scores, or the increase in MFR scores between the EG and the CG.

MFR scores were, within both groups, significantly higher $1-2$ weeks after the intervention than $1-2$ weeks before the intervention $(p<0.0001$ in all cases $)$.

After screening offer women in EG1 and EG2 had higher MFR scores compared to women in the CG $(\mathrm{p}<0.001)$. This difference disappeared later in pregnancy.

After screening result was received women in the CG had higher MFR scores compared to negatively screened EG2 $(p=0.003)$, but not compared to negatively screened EG1 women.

No follow-up.

No blinding.

Non-concurrent group interventions (time difference of approximately 1 year)

Non-random assignment to groups.

No documented power analysis.

Preferential use of selfdeveloped, non-validated tool.

High attrition rate.

All significant results had low effect sizes.

Unclear whether the PAI had been translated and validated.

Dimensionality of the scan did not have an effect No baseline measurement. on the MFR $(\mathrm{p}<0.9)$

Unclear how many women were in each group.

Internal

Validity:

External

Validity:

Use of self-developed, nonvalidated tool.
Internal

External

Validity:

Internal Validity:

External

Validity:

Internal

Validity:

External

Validity: 
Table I - Data Summary Table (Cont.)

\begin{tabular}{|c|c|c|c|c|c|}
\hline $\begin{array}{l}\text { Authors } \\
\text { (Publication Year), } \\
\text { Location }\end{array}$ & $\begin{array}{l}\text { Study Design, } \\
\text { Sample Size, } \\
\text { Relevant Scale } \\
\text { Used }\end{array}$ & Intervention & Key Relevant Outcomes & Main Limitations & Quality* \\
\hline $\begin{array}{l}\text { Öhman and } \\
\text { Waldenström }{ }^{34} \text {, } \\
(2010) \text {, } \\
\text { Sweden }\end{array}$ & $\begin{array}{l}\text { RCT, } \\
2026 \text { women, } \\
\text { Modified } \\
\text { MFAS }^{28}\end{array}$ & $\begin{array}{l}\text { EG received an ultrasound examination between } \\
\text { gestational weeks } 12-14 \text {, which included } \\
\text { screening for Down Syndrome. } \\
\text { CG received a routine ultrasound scan between } \\
\text { gestational weeks } 15-20 \text {. }\end{array}$ & $\begin{array}{l}\text { At } 24 \text { weeks' gestation, the EG had higher } \\
\text { total MFR scores than the CG }(\mathrm{p}=0.04) \text {. } \\
\text { With regards to subscale scores, group } \\
\text { differences were only significant for } \\
\text { 'differentiation of self from fetus' }(\mathrm{p}=0.01) \text {. }\end{array}$ & $\begin{array}{l}\text { No pre-intervention } \\
\text { measurement of MFR. } \\
\text { Unclear whether the MFAS } \\
\text { had been translated and } \\
\text { validated. }\end{array}$ & $\begin{array}{l}\text { Internal } \\
\text { Validity: } \\
\quad+ \\
\text { External } \\
\text { Validity: } \\
\quad+\end{array}$ \\
\hline $\begin{array}{l}\text { Pretorius et al. }{ }^{32} \\
\text { (2006), } \\
\text { USA }\end{array}$ & $\begin{array}{l}\text { Non-comparative } \\
\text { study, } \\
189(124 \text { women, } \\
65 \text { men }) \\
\text { MFAS }^{28}\end{array}$ & $\begin{array}{l}\text { Women received a 3D ultrasound examination, } \\
\text { generally immediately after a 2D ultrasound, } \\
\text { during which normal anatomic structures of the } \\
\text { fetus were pointed out. Male participants were } \\
\text { present for the examination. }\end{array}$ & $\begin{array}{l}\text { A positive change in MFR from before to after } \\
\text { the } 3 D / 4 D \text { ultrasound that was statistically } \\
\text { significant for both men }(p=0.007) \text { and } \\
\text { women }(p<0.0001) \text {. }\end{array}$ & $\begin{array}{l}\text { No control group. } \\
\text { No follow up. }\end{array}$ & $\begin{array}{l}\text { Internal } \\
\text { Validity: } \\
\quad- \\
\text { External } \\
\text { Validity: }\end{array}$ \\
\hline $\begin{array}{l}\text { Righetti et al. }{ }^{36} \\
(2005) \text {, } \\
\text { Italy }\end{array}$ & $\begin{array}{l}\text { RCT, } \\
112 \text { (56 women, } \\
56 \text { men), } \\
\text { MAAS/PAAS }^{6}\end{array}$ & $\begin{array}{l}\text { EG received (women)/observed (men) a } 4 \mathrm{D} \\
\text { ultrasound. } \\
\text { CG received (women)/observed (men) a } 2 \mathrm{D} \\
\text { ultrasound. }\end{array}$ & $\begin{array}{l}\text { Ultrasound modality did not have a significant } \\
\text { influence on change in PFR over time. } \\
\text { For women (but not men) in both groups there } \\
\text { was a significant pre-post main effect in global } \\
\text { MFR and quality of attachment. }\end{array}$ & $\begin{array}{l}\text { Unclear whether the } \\
\text { MAAS/PAAS had been } \\
\text { translated and validated. } \\
\text { No blinding. }\end{array}$ & $\begin{array}{l}\text { Internal } \\
\text { Validity: } \\
\quad+ \\
\text { External } \\
\text { Validity: } \\
\quad+\end{array}$ \\
\hline $\begin{array}{l}\text { Rustico et al. } \\
(2005) \\
\text { Italy }\end{array}$ & $\begin{array}{l}\text { RCT, } \\
100 \text { women, } \\
\text { MAAS }^{6}\end{array}$ & $\begin{array}{l}\text { EG received a } 2 \mathrm{D} \text { and a } 4 \mathrm{D} \text { ultrasound. } \\
\text { CG received a } 2 \mathrm{D} \text { ultrasound. }\end{array}$ & $\begin{array}{l}\text { There were no significant differences in MFR } \\
\text { mean scores between the two groups. }\end{array}$ & $\begin{array}{l}\text { Only a subgroup of } 46 \text { women } \\
\text { completed the MAAS. } \\
\text { No baseline measurement. }\end{array}$ & $\begin{array}{l}\text { Internal } \\
\text { Validity: } \\
- \\
\text { External } \\
\text { Validity: } \\
\quad-\end{array}$ \\
\hline $\begin{array}{l}\text { Sedgmen et al. } .^{35} \text { (2006), } \\
\text { Australia }\end{array}$ & $\begin{array}{l}\text { Non-RCT, } \\
116 \text { women, } \\
\text { MAAS }^{6}\end{array}$ & $\begin{array}{l}\text { EG received a } 2 \mathrm{D} \text { and a } 3 \mathrm{D} \text { ultrasound. } \\
\mathrm{CG} \text { received a } 2 \mathrm{D} \text { ultrasound. }\end{array}$ & $\begin{array}{l}\text { MFR scores increased significantly over study } \\
\text { for both groups }(\mathrm{p}<0.01) \text {. Patterns of change } \\
\text { over time were not significantly different } \\
\text { between groups. } \\
\text { Increase in the MFR was greater }(\mathrm{p}<0.01) \text { for } \\
\text { women at } 12 \text { weeks' gestation/first- timers } \\
\text { than it was for women at } 18 \text { weeks/repeat } \\
\text { ultrasound }\end{array}$ & $\begin{array}{l}\text { Non-random allocation to } \\
\text { groups. } \\
\text { No reported power analysis. } \\
\text { High attrition rate. }\end{array}$ & $\begin{array}{l}\text { Internal } \\
\text { Validity: } \\
\quad+ \\
\text { External } \\
\text { Validity: } \\
\quad+\end{array}$ \\
\hline
\end{tabular}


Table I - Data Summary Table (Cont.)

\begin{tabular}{lll}
\hline $\begin{array}{l}\text { Authors } \\
\text { (Publication Year), }\end{array}$ & $\begin{array}{l}\text { Study Design, } \\
\text { Sample Size, } \\
\text { Lecation }\end{array}$ & Intervention \\
Relevant Scale & & Key Relevant Outcomes \\
& &
\end{tabular}

Fetal Awareness Interventions

Nishikawa and

Observational

Hisataka Sakakibara ${ }^{43}$ Study,

(2013)

Japan

227 women

$\mathrm{PAI}^{30}$

received 3 individual sessions of abdomina

examination through Leopold's Manoeuvres,

followed by group discussion.

CG participated in pre-mothers' classes.

Rincy and Nalini ${ }^{41}, \quad$ RCT,

(2014),

100 women,

$\mathrm{PAI}^{30}$

EG received formal instruction to monitor fetal movement and maintain a kick chart, twice daily for 14 days.

CG received routine antenatal teaching.

RCT,

Saastad et al. ${ }^{42}$

(2011),

Norway

1,155 women

$\mathrm{PAI}^{30}$

EG received instructions to count fetal movement

from gestational week 28 (time to reach 10

movements).

CG received routine care.

\section{Relaxation Strategies}

Chang et al. ${ }^{54}$

(2015),

Taiwan

RCT

320 women,

Merged MFAS ${ }^{2}$

and $\mathrm{PAI}^{30}$

EG were instructed to listen to relaxation music

on provided $\mathrm{CD}$ for 30 mins per day for 2 weeks.

CG received routine care.
MFR scores increased significantly at the

32nd, 34th, and 36th weeks' gestation time

points, compared to baseline, for both groups

At 34 and 36 weeks' gestation the EG scored higher than the CG on MFR ( $p<0.01$ and $p<$ 0.05 , respectively)

There was an improvement in MFR scores in the EG between pre-test and post-test $(\mathrm{p}<$

$0.001)$. No statistical significance difference

was seen within the $\mathrm{CG}$

In the post-test, the EG scored higher than the CG on MFR measure $(\mathrm{p}<0.001)$

No significant differences were found

between the groups in MFR scores .

measurement of the PFR.

No statistically significant differences in terms No documented power analysis. of MFR between the post-test results of the two groups.
Lack of cultural diversity.

High attrition rate.

Internal

Self-selection of group

assignment.

Validity:

External

Validity:

No reported power analysis. Internal

No blinding.

Sample was limited to those speaking Tamil and English.

Validity:

External

Validity:

Internal

Validity:

+
External

Validity:

$+$

Internal

Validity:

Routine music listening habits

not measured in the control

xternal

External 
Table I - Data Summary Table (Cont.)

\begin{tabular}{|c|c|c|c|c|c|}
\hline $\begin{array}{l}\text { Authors } \\
\text { (Publication Year), } \\
\text { Location }\end{array}$ & $\begin{array}{l}\text { Study Design, } \\
\text { Sample Size, } \\
\text { Relevant Scale } \\
\text { Used }\end{array}$ & Intervention & Key Relevant Outcomes & Main Limitations & Quality* \\
\hline $\begin{array}{l}\text { Latifses et al. }{ }^{57} \\
(2005) \text {, } \\
\text { USA }\end{array}$ & $\begin{array}{l}\text { RCT, } \\
175 \text { men, } \\
\text { PFAS }^{29}\end{array}$ & $\begin{array}{l}\text { EG were taught to massage their pregnant } \\
\text { wives. They were asked to follow the routine at } \\
\text { home two times a week for } 20 \text { minutes each } \\
\text { time. } \\
\text { CG received routine care. }\end{array}$ & $\begin{array}{l}\text { The paternal-fetal relationship improved over } \\
\text { time for men in both groups }(\mathrm{p}=0.001) \text {. } \\
\text { Patterns of change over time were not } \\
\text { significantly different between groups. }\end{array}$ & $\begin{array}{l}\text { Unclear how many fathers } \\
\text { were in each group. } \\
\text { Compliance to intervention } \\
\text { was not measured. }\end{array}$ & $\begin{array}{l}\text { Internal } \\
\text { Validity: } \\
\quad+ \\
\text { External } \\
\text { Validity: } \\
\quad-\end{array}$ \\
\hline $\begin{array}{l}\text { Muzik et al. }{ }^{56} \\
(2012) \\
\text { USA }\end{array}$ & $\begin{array}{l}\text { Non-comparative } \\
\text { study, } \\
22 \text { women, } \\
\text { MFAS }^{28}\end{array}$ & $\begin{array}{l}\text { Women participated in a } 10 \text {-week prenatal } \\
\text { "Mindfulness Yoga" programme to improve } \\
\text { wellbeing and decrease stress, with each weekly } \\
\text { session lasting } 90 \text { minutes. }\end{array}$ & $\begin{array}{l}\text { MFR scores increased significantly overall }(\mathrm{p}< \\
0.01) \text { and on all five subscales of the MFAS } \\
\text { from pre-to post-intervention measurement. }\end{array}$ & $\begin{array}{l}\text { No control group. } \\
\text { No documented power } \\
\text { analysis. }\end{array}$ & $\begin{array}{l}\text { Internal } \\
\text { Validity: } \\
\text { - } \\
\text { External } \\
\text { Validity: }\end{array}$ \\
\hline $\begin{array}{l}\text { Shin and } \mathrm{Kim}^{55} \\
(2011) \text {, } \\
\text { Korea }\end{array}$ & $\begin{array}{l}\text { Before and After } \\
\text { Study, } \\
240 \text { women, } \\
\text { MFAS }^{28}\end{array}$ & $\begin{array}{l}\text { EG received a transvaginal ultrasound during } \\
\text { which they listened to } 30 \text {-minutes of music with } \\
\text { nature sounds. } \\
\text { CG received routine care. }\end{array}$ & $\begin{array}{l}\text { There were no significant differences between } \\
\text { the two groups in post-test MFR scores }(\mathrm{p}= \\
0.659) \text {. }\end{array}$ & $\begin{array}{l}\text { Non-concurrent measurement } \\
\text { between groups. } \\
\text { No follow-up. }\end{array}$ & $\begin{array}{l}\text { Internal } \\
\text { Validity: } \\
+ \\
\text { External } \\
\text { Validity: }\end{array}$ \\
\hline \multicolumn{6}{|c|}{ Educational Programmes } \\
\hline $\begin{array}{l}\text { Abasi et al }{ }^{48} \\
\text { (2013), } \\
\text { Iran }\end{array}$ & $\begin{array}{l}\text { RCT, } \\
83 \text { women, } \\
\text { MFAS }^{28}\end{array}$ & $\begin{array}{l}\text { EG received four weekly sessions of } \\
\text { education concerning attachment. } \\
\text { CG received routine care. }\end{array}$ & $\begin{array}{l}\text { MFR scores in the EG increased significantly } \\
\text { from pre-to post-intervention measurement }(\mathrm{p}< \\
0.001) \text {. } \\
\text { The mean difference between MFR scores before } \\
\text { and after treatment due to group division was } \\
\text { significant }(\mathrm{p}<0.001) \text {. }\end{array}$ & $\begin{array}{l}\text { Number of women in each } \\
\text { group not specified. } \\
\text { Method of randomisation of } \\
\text { healthcare centres not } \\
\text { specified. }\end{array}$ & $\begin{array}{c}\text { Internal } \\
\text { Validity: } \\
- \\
\text { External } \\
\text { Validity: } \\
\quad-\end{array}$ \\
\hline $\begin{array}{l}\text { Akbarzade et al. } .^{31} \\
(2014) \text {, } \\
\text { Iran }\end{array}$ & $\begin{array}{l}\text { RCT, } \\
150 \text { women, } \\
\text { MFAS }^{28}\end{array}$ & $\begin{array}{l}\text { EG women's husbands attended four, weekly, } \\
\text { educational sessions concerning attachment } \\
\text { lasting } 60-90 \text { minutes and a reminder session. } \\
\text { They were asked to pass on the information } \\
\text { gained to their wives. }\end{array}$ & $\begin{array}{l}\text { There was an improvement in MFR scores in the } \\
\text { EG between pre-test and post-test }(\mathrm{p}< \\
0.001) \text {. No statistical significance difference was } \\
\text { seen within the CG }(\mathrm{p}<0.660) \text {. } \\
\text { In the post-test, the EG scored higher than the } \\
\text { CG on MFR measure }(\mathrm{p}<0.05) \text {. }\end{array}$ & $\begin{array}{l}\text { No blinding. } \\
\text { Adherence to programme not } \\
\text { specified. }\end{array}$ & $\begin{array}{c}\text { Internal } \\
\text { Validity: } \\
+ \\
\text { External } \\
\text { Validity: } \\
+\end{array}$ \\
\hline
\end{tabular}


Table I - Data Summary Table (Cont.)

\begin{tabular}{|c|c|c|c|c|c|}
\hline $\begin{array}{l}\text { Authors } \\
\text { (Publication Year), } \\
\text { Location }\end{array}$ & $\begin{array}{l}\text { Study Design, } \\
\text { Sample Size, } \\
\text { Relevant Scale } \\
\text { Used }\end{array}$ & Intervention & Key Relevant Outcomes & Main Limitations & Quality* \\
\hline $\begin{array}{l}\text { Bellieni et al. }{ }^{47} \text {, } \\
(2007), \\
\text { Italy }\end{array}$ & $\begin{array}{l}\text { Observational } \\
\text { Study, } \\
77 \text { women, } \\
\text { PAI }^{30}\end{array}$ & $\begin{array}{l}\text { EG attended five, } 60 \text {-minute group lessons that } \\
\text { aimed to raise awareness of fetal presence and } \\
\text { development, and encourage interaction. } \\
\text { CG received routine care. }\end{array}$ & $\begin{array}{l}\text { At post-test the EG had significantly higher } \\
\text { MFR scores than the CG }(p<0.05) \text {. }\end{array}$ & $\begin{array}{l}\text { No baseline MFR } \\
\text { measurement. } \\
\text { Self-selection of group } \\
\text { allocation. }\end{array}$ & $\begin{array}{l}\text { Internal } \\
\text { Validity: } \\
- \\
\text { External } \\
\text { Validity: }\end{array}$ \\
\hline $\begin{array}{l}\text { Burke }^{45} \\
\text { (2007), } \\
\text { USA }\end{array}$ & $\begin{array}{l}\text { Non-Comparative } \\
\text { Study, } \\
12 \text { women, } \\
\text { PAI }^{30}\end{array}$ & $\begin{array}{l}\text { Women participated in a 3-day, } 18 \text {-hour training } \\
\text { programme which included teaching of maternal } \\
\text { bonding techniques that encourage expectant } \\
\text { parents to communicate with their fetuses. }\end{array}$ & $\begin{array}{l}\text { MFR scores increased significantly overall }(\mathrm{p}= \\
0.001) \text { from pre- to post-intervention } \\
\text { measurement. }\end{array}$ & $\begin{array}{l}\text { No control group. } \\
\text { Small sample size. }\end{array}$ & $\begin{array}{l}\text { Internal } \\
\text { Validity: } \\
\quad- \\
\text { External } \\
\text { Validity: } \\
\quad+\end{array}$ \\
\hline $\begin{array}{l}\text { Thomas et al. }{ }^{46} \\
(2014) \text {, } \\
\text { Australia }\end{array}$ & $\begin{array}{l}\text { Non-Comparative } \\
\text { Study, } \\
48 \text { women with, } \\
\text { or at risk of, } \\
\text { depression, } \\
\text { MAAS }^{6}\end{array}$ & $\begin{array}{l}\text { Women participated in six bi-weekly } \\
\text { educational sessions lasting } 2 \text { hours each. } \\
\text { Women's partners attended two of the sessions. } \\
\text { Included a parent-infant relationship component } \\
\text { addressing infant attachment needs, positive } \\
\text { parental responsiveness and bonding with } \\
\text { infants. }\end{array}$ & $\begin{array}{l}\text { MFR scores increased significantly overall }(\mathrm{p}= \\
0.006) \text { from pre- to post-intervention } \\
\text { measurement. }\end{array}$ & $\begin{array}{l}\text { No control group. } \\
\text { The majority of the } \\
\text { participants }(98 \%) \text { were } \\
\text { receiving concurrent } \\
\text { individual mental health } \\
\text { treatment. }\end{array}$ & $\begin{array}{c}\text { Internal } \\
\text { Validity: } \\
\quad- \\
\text { External } \\
\text { Validity: } \\
\quad+\end{array}$ \\
\hline \multicolumn{6}{|c|}{ Social and Psychological Support Techniques } \\
\hline $\begin{array}{l}\text { Côté-Arsenault et al. }{ }^{50} \\
\text { (2014), } \\
\text { USA }\end{array}$ & $\begin{array}{l}\text { RCT }+ \\
\text { Qualitative } \\
\text { Component, } \\
24 \text { women with a } \\
\text { history of } \\
\text { perinatal loss, } \\
\text { MAAS }^{6}\end{array}$ & $\begin{array}{l}\text { EG received a caring intervention incorporating } \\
6 \text { home visits, the keeping of a pregnancy diary } \\
\text { and teaching of anxiety-reducing skills. } \\
\text { CG received pregnancy information booklets. }\end{array}$ & $\begin{array}{l}\text { No statistically significant differences in terms } \\
\text { of MFR were found between the post-test results } \\
\text { of the two groups. } \\
\text { Qualitative analysis suggested that for half of the } \\
\text { women the intervention interfered with a } \\
\text { tendency to supress fetal bonding. }\end{array}$ & $\begin{array}{l}\text { Sampling method is not } \\
\text { specified. } \\
\text { Lack of cultural diversity. }\end{array}$ & $\begin{array}{l}\text { Internal } \\
\text { Validity: } \\
\quad+ \\
\text { External } \\
\text { Validity: } \\
\quad+\end{array}$ \\
\hline $\begin{array}{l}\text { Flykt et al. }{ }^{52} \\
(2012), \\
\text { Finland }\end{array}$ & $\begin{array}{l}\text { Observational } \\
\text { study, } \\
101 \text { drug-abusing } \\
\text { women and } \\
\text { controls, } \\
\text { IRMAG }\end{array}$ & $\begin{array}{l}\text { EG1 received psychodynamic group therapy } \\
\text { comprising } 20-24 \text {, weekly sessions lasting } 3 \\
\text { hours each and starting in pregnancy. } \\
\text { EG2 received psychosocial support. } \\
\text { CG received routine care. }\end{array}$ & $\begin{array}{l}\text { Among EG } 2 \text { women, representations of the child } \\
\text { first changed in a more positive direction from } \\
\mathrm{T} 1 \text { to } \mathrm{T} 2 \text { and then back in a more negative } \\
\text { direction from } \mathrm{T} 2 \text { to } \mathrm{T} 3 \text {, whereas there was no } \\
\text { change among the CG women, and a mild, } \\
\text { nonsignificant positive change among the EG1 } \\
\text { women. }\end{array}$ & $\begin{array}{l}\text { Self-selection of group } \\
\text { allocation. } \\
\text { No documented power } \\
\text { analysis. }\end{array}$ & $\begin{array}{l}\text { Internal } \\
\text { Validity: } \\
\quad+ \\
\text { External } \\
\text { Validity: } \\
\quad+\end{array}$ \\
\hline
\end{tabular}


Table I - Data Summary Table (Cont.)

\begin{tabular}{|c|c|c|c|c|c|}
\hline $\begin{array}{l}\text { Authors } \\
\text { (Publication Year), } \\
\text { Location }\end{array}$ & $\begin{array}{l}\text { Study Design, } \\
\text { Sample Size, } \\
\text { Relevant Scale } \\
\text { Used }\end{array}$ & Intervention & Key Relevant Outcomes & Main Limitations & Quality* \\
\hline $\begin{array}{l}\text { Lavi et al. } .^{53} \\
(2015) \text {, } \\
\text { USA }\end{array}$ & $\begin{array}{l}\text { Non- } \\
\text { Comparative } \\
\text { Study, } \\
94 \text { women at risk } \\
\text { of domestic } \\
\text { abuse, } \\
\text { MFAS }^{28}\end{array}$ & $\begin{array}{l}\text { Women attended weekly child-parent } \\
\text { psychotherapy sessions from pregnancy until the } \\
\text { infant was } 6 \text { months old. Number of treatment } \\
\text { session ranged from 12- } 49 \text { (average: } 27 \text { ). The } \\
\text { intervention aimed to promote attunement and } \\
\text { responsiveness to the child, and address negative } \\
\text { maternal attributions of infant and potentially } \\
\text { maladaptive caregiving behaviours. }\end{array}$ & $\begin{array}{l}\text { The greatest improvement in depression, } \\
\text { posttraumatic stress symptoms, and child-rearing } \\
\text { attitudes were observed in women who reported } \\
\text { a weak MFR. }\end{array}$ & $\begin{array}{l}\text { No control group } \\
\text { Large variation in gestational } \\
\text { age at recruitment } \\
\text { Unclear whether translated } \\
\text { MFAS }{ }^{28} \text { had been validated. }\end{array}$ & $\begin{array}{l}\text { Internal } \\
\text { Validity: } \\
\quad- \\
\text { External } \\
\text { Validity: } \\
\quad+\end{array}$ \\
\hline $\begin{array}{l}\text { Scherer et al. } \\
(2014) \text {, } \\
\text { Switzerland }\end{array}$ & $\begin{array}{l}\text { Case Study, } \\
1 \text { woman with } \\
\text { cervical } \\
\text { insufficiency, } \\
\text { Prenatal Bonding } \\
\text { Questionnaire }^{59}\end{array}$ & $\begin{array}{l}\text { Woman participated in a } 6 \text {-week, cognitive- } \\
\text { behavioural self-help, online program. It } \\
\text { provided strategies to reduce anxiety and stress. }\end{array}$ & $\begin{array}{l}\text { The Prenatal Bonding score increased from } 56 \\
\text { pre-treatment, to } 62 \text { post-treatment. }\end{array}$ & $\begin{array}{l}\text { Case-report of a single } \\
\text { participant. } \\
\text { MFR measured using a little } \\
\text { known, not fully validated } \\
\text { tool. }\end{array}$ & $\begin{array}{c}\text { Internal } \\
\text { Validity: } \\
- \\
\text { External } \\
\text { Validity: } \\
\quad-\end{array}$ \\
\hline $\begin{array}{l}\text { Spinelli et al. }{ }^{51} \\
(2013) \\
\text { USA }\end{array}$ & $\begin{array}{l}\text { RCT, } \\
142 \text { women with } \\
\text { antenatal } \\
\text { depression, } \\
\text { MFAS }^{28}\end{array}$ & $\begin{array}{l}\text { EG received interpersonal psychotherapy } \\
\text { intervention (not described in paper) } \\
\text { CG participated in parenting education } \\
\text { programme consisting of individual, therapist- } \\
\text { led, } 45 \text {-minute, weekly educational sessions over } \\
12 \text { weeks. }\end{array}$ & $\begin{array}{l}\text { Scores relating to MFR between groups are } \\
\text { demonstrated through a graph. It visually } \\
\text { appears that they did not differ notably between } \\
\text { groups at any point during the treatment. }\end{array}$ & $\begin{array}{l}\text { Intervention poorly } \\
\text { described. } \\
\text { Intervention group did not } \\
\text { receive control group care. }\end{array}$ & $\begin{array}{l}\text { Internal } \\
\text { Validity: } \\
\quad+ \\
\text { External } \\
\text { Validity: } \\
+\end{array}$ \\
\hline $\begin{array}{l}\text { Weis and } \text { Ryan }^{49} \\
\text { (2012), } \\
\text { USA }\end{array}$ & $\begin{array}{l}\text { RCT, } \\
65 \text { military } \\
\text { wives, } \\
\text { MAAS }^{6}\end{array}$ & $\begin{array}{l}\text { EG participated in programme consisting of } \\
\text { eight, bi-weekly, semi-structured support } \\
\text { sessions, lasting } 1.5 \text { hours each, with unlimited } \\
\text { support from a trained mentor. } \\
\text { CG received routine care. }\end{array}$ & $\begin{array}{l}\text { No statistically significant differences in terms of } \\
\text { MFR were found between the two groups. }\end{array}$ & $\begin{array}{l}\text { Very low recruitment rate. } \\
\text { No follow-up after } \\
\text { intervention end. }\end{array}$ & $\begin{array}{l}\text { Internal } \\
\text { Validity: } \\
\quad+ \\
\text { External } \\
\text { Validity: } \\
\quad+\end{array}$ \\
\hline
\end{tabular}

Legend: 3D (3-Dimentional), 4D (4-Dimentional), CG (Control Group), EG (Experimental Group), IRMAG (Interview of Maternal Representations), MAAS (Maternal Antenatal Attachment Scale), MFAS (Maternal-Fetal Attachment Scale), MFR (Maternal-Fetal Relationship), PAI (Prenatal Attachment Inventory), PAAS (Paternal Antenatal Attachment Scale), PFAS (PaternalFetal Attachment Scale), PFR (Paternal-Fetal Relationship), RCT (Randomised Controlled Trial).

* Assigned on the basis of the 'quality appraisal checklist for intervention studies', part of the revised 'Graphical Appraisal Tool for Epidemiological Studies (GATE), 24,25 . 
Figure I - Search Terms Used

\begin{tabular}{|c|c|c|c|}
\hline Criterion A & Criterion B & Criterion C & Criterion D \\
\hline Prenatal & $\mathrm{F}^{*}$ etal & Attachment & Clinical Trial \\
\hline OR Antenatal & OR F*etus & OR Relationship & $\begin{array}{l}\text { OR Experimental } \\
\text { Study }\end{array}$ \\
\hline OR Maternal & & OR Representation & OR Controlled Trial \\
\hline OR Paternal & & OR Bond* & OR Controlled Study \\
\hline OR Parental & & & OR Intervention* \\
\hline OR Mother & & & OR Random \\
\hline OR Father & & & OR Random \\
\hline \multirow[t]{3}{*}{ OR Parent } & & & OR Experimental \\
\hline & & & OR Control Group \\
\hline & & & OR Randomi*ed \\
\hline
\end{tabular}


Figure II - Identification of Studies

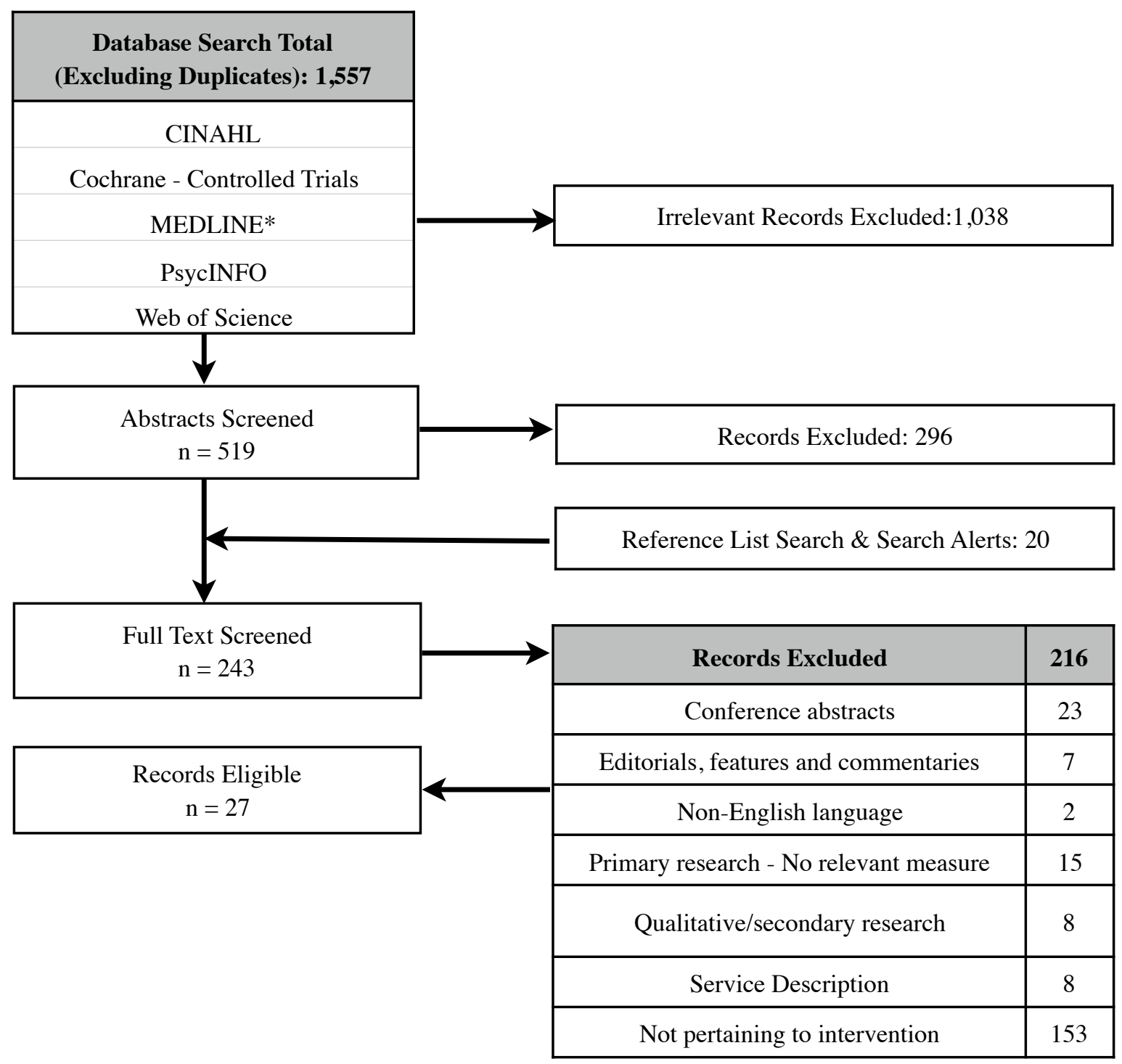

